\title{
Impetuses and Problems of Sino - Russian Energy Cooperation
}

\author{
Yulia Grama ${ }^{1}$ \\ ${ }^{1}$ Department of Diplomacy, National Chengchi University, Taipei, R.O.C. \\ Correspondence: Yulia Grama, Department of Diplomacy, National Chengchi University, PO box No.64, Sec.2, \\ ZhiNan Rd., Wenshan District, NCCU, Taipei 11605, R.O.C. Tel: 886-983-425-399. E-mail: \\ 97253504@nccu.edu.tw
}

Received: February 19, 2012

Accepted: March 19, $2012 \quad$ Published: June 1, 2012

doi:10.5539/ass.v8n7p45

URL: http://dx.doi.org/10.5539/ass.v8n7p45

\begin{abstract}
The article is devoted to the analysis of Sino-Russian energy cooperation: its impetuses, development, achievements and problems. Obviously, both countries have a great potential for the intense energy cooperation, but the analysis of its content and recent development reveals that there are some serious problems on the way to the closest and mutually beneficial energy dialog between China and Russia. But, at the end the author came to conclusion that despite these negative factors, Sino-Russian relationship has significant reserves and both countries objectively need to improve and deepen their strategic partnership.
\end{abstract}

Keywords: Russia, China, energy cooperation, energy diplomacy, oil, gas, nuclear energy

\section{Introduction}

Energy is one of the important factors to the survival of humanity. It provides heat, light and mobility, the fuel of the economy. This is why the possession of energy is a dominant issue in the politics of every country. In the $21^{\text {st }}$ century, with both the tremendous growth in the world's population and energy consumption, energy related issues have risen to the top in both the national and international agendas of the states. The Global energy market is increasingly influenced by the location of the resources and the political and economic environment; growing demand from the developing world, particularly from China and India; climate change, manipulation of resources for non-energy foreign policy objectives; and others (Mattews, 2008).

Because of the non-proportional distribution of energy resources there is a strong competition for energy supply and markets in the world arena. Countries have to diversify import sources and fuel to increase storage capacity, to protect the supplying infrastructure. Thus, the question of diversification of energy importation is the key question on the energy policy agenda of importing countries. Countries which are supplying energy recourses are also seeking for stable and growing markets in order to diversify their partners increase their own export and be able to conduct independent energy policy to their own advantage.

The tremendous economic development of China is the most discussed phenomenon nowadays. China has been witnessing a steady increase in their energy consumption for many years. Increasing economic growth characterized by high industrial activity is the main reason behind it. That is why China is actively seeking for more opportunities to import energy resources and thus, exporting countries are also interested in this huge market.

Obviously, there are many reasons for Sino-Russian energy cooperation. Russia is one of the world's largest energy producers: it holds the position of one of the world's largest exporter of oil and natural gas. China has great demand for energy resources and power as it strives to build its economy and supply its population with electricity. This relationship has been characterized by Anders Aslund of the Peterson Institute as "having enormous complementarities between Russia, which has commodities, and China, which has cheap labour and manufacturing" (Rosner, 2009).

The easing of tensions in Northeast Asia and in the world after the end of the Cold War and the improvement and furtherance of Russo-Chinese relations has provided a good environment and necessary conditions for bilateral energy cooperation. 
The fact that China and Russia are neighbours is a compelling reason for expanded energy exports from Russia to China. The two countries share a 4,200 kilometres border. This geographical proximity allows for a direct trade free from third-party countries, which require transit fees and have the power to withhold supplies.

So, there seem to be complementary interests between China and Russia in the energy trade. Russia has abundant gas and oil resources, and China is an energy importer. The diversification of customers seems to make good business sense for Russia, while China seeks secure energy sources which are not threatened by the volatility of the Middle East or a sea blockade. However, energy is much more than about trade, it is closely linked with the questions of national power and interest and the energy relationship between China and Russia is a touchstone of their overall relationship.

\section{The History and Recent Development of Russo-Chinese Energy Cooperation}

Sino- Russian energy cooperation can be divided into 3 stages.

\subsection{The First Stage - Years of 1990 s}

At this stage Russia was very enthusiastic and active about the energy dialogue with China and it was the main peculiarity of this period. In the beginning of the 1990's the economic, political situation and the foreign policy of Russia was in chaos, the country was seeking ways for future development and had no concrete and elaborated plans and strategies. After the collapse of the Soviet Union, one of the possible ways to overcome the economic disaster develop eastern regions and strengthen the country foreign policy was the trade of energy resources, thus Russia was actively looking for energy cooperation with China. But for China, at that time, the question of the shortage of energy resources was not so important. The country had not achieved such a level of economic and industrial development to require more energy recourses. And the only way for Russia to supply energy resources to China was by railway, which made it expensive, not effective and not safe. Also, China lacked knowledge about the energy situation in Russia and possible ways of cooperation. Thus, China was not interested in energy cooperation with Russia and lost its perfect chance to receive gains from pursuing a relationship.

\subsection{The Second Stage - End of 1990s till 2005}

The main peculiarity of this period could be that China started to look actively for energy dialogue with Russia, but Russia had already started its "energy games" in the international arena. So, if China was interested in cooperation in this area with Russia, then Russia did not find the balance, it kept its "left and right" strategy, because it was looking for the most favourable scenario of energy diplomacy in accordance with national interests. With tremendous economic and industrial growth China faced the problem of shortage of energy resources, its domestic supplies were not able to cover the demand of the rapidly growing economy anymore, and thus the country started to look for sources of energy import and, naturally, approached Russia.

In June 2000, Russian president Putin first visited China. During the visit seven inter-government and inter-department agreements were signed, including the Joint Statement with Chinese President Jiang Zemin reassuring the strategic relations between the two countries and memorandums and contracts between CNPC and Russian Yukos. Relations between the two countries intensified and in June 2001 the Russian-Chinese Treaty on Good-Neighbourliness, Friendship and Cooperation was signed (Note 1). The Treaty specified a long-term legal foundation for developing Russian-Chinese strategic partnership and was the first treaty since the Soviet-Chinese Treaty of the Friendship dates 1950.

In September 2001, CNPC and Yukos signed a frame agreement about the construction of a $2400 \mathrm{~km}$ oil pipeline from Russian Angarsk to Chinese Daqing. The construction of the pipeline was planned to be finished by 2005 . It was estimated that the total annual throughput would be 30 million tons and that Yukos would provide no less than 50 percent of this supply (Andrews-Speed, 2009).

The governments of both countries were lobbying this project. The joint statement signed by President Jiang Zemin and the visiting Russian President Vladimir Putin in early December 2002 declared: "Considering the important significance of energy cooperation for the two sides, heads of state of the two countries held that guaranteeing the scheduled implementation of the Russo-Chinese crude oil pipeline and natural gas pipeline cooperation project as contained in the agreement, and the coordinated implementation of promising energy projects is of vital importance for ensuring stable, long-term oil/gas supply" (People's Daily ,2003).

At that time the main content of the energy dialogue between the two states was oil, it also represented a huge stake in the political game. Siberian hydrocarbon riches are set to remain a field of competition between energy-thirsty East Asian economies. Russia's position is unique in terms of oil reserves. Moscow could offer 
massive acreage in eastern Siberia, while the country's oil reserves are still big enough to support booming oil exports for decades to come (Blagov, 2012).

At that time it was not only China who was very interested in the supply of Russian crude oil, but also other countries in the Asia pacific, in particular, Japan. Putin's government decided to gain from this situation and in November 2002 Kremlin's came with the decision to approve the East Siberia-Pacific oil pipeline to the port of Nakhodka, and thus, toward Japan. This came as a blow to China's hopes of securing its own energy resources at the stake of Russia's hydrocarbons.

The energy dialogue between China and Russia underwent another trial in December 2002. China National Petroleum Corp (CNPC) decided to bid for a 74.95 percent state-owned stake in the Russian oil company, Slavneft. CNPC was seen as the strongest contender, however, Russia's Privatization Fund ruled the company out, citing its state-owned status (Datamonitor Research Store, 2011). There was no clear explanation from the Russian side about this decision, but it strained already not easy energy relations between Russia and China. The Russo-Chinese energy relations had to face new realities and changes and had to review the direction of further development.

\subsection{The Third Stage - 2006 till Nowadays}

During this period Russo-Chinese energy relations came into a new and intensified stage.

In March 2006, the Russian president Putin came to China on an official visit. In order to be actively involved in international politics not only in the Asia Pacific region, but in the world, Russia needed to seek deeper and more intensified cooperation with China in all areas. The supply of Russian energy recourse would be a good stimulus for China to stimulate such cooperation, thus this trip was unofficially known as "the energy trip". This visit was made by the invitation of the Chinese president Hu Jintao, which showed that interest was mutual. Before this visit, Chinese Foreign minister Li Zhaoxing said that: "The visit is expected to boost the all-round development of the Russo-Chinese Strategic Partnership of Cooperation, and facilitate world peace, stability and development" (China Daily, March 17, 2006).

This visit has transformed the balance of power across Eurasia. Russian Foreign Minister Sergei Lavrov told a press conference in Beijing Wednesday that the strategic partnership between the two giant nations was "irreversible" (Sieff, 2009).

Twenty two cooperation agreements between the two countries were signed during the two-day state visit. Russian President Vladimir Putin and his Chinese colleague Hu Jintao discussed the pipeline project and the Chinese side received a promise that the oil pipeline will be extended from Russia's Skovorodino to the Russia-China border. Before the completion of the pipeline Russia would supply oil to China via the railway. Russia planned to supply 15 million tons of crude oil to China by railway in 2006 (China Daily, March 17, 2006). In addition, the two countries discussed exports of natural gas to China. Both leaders agreed that the energy cooperation between Russia and China had a broad prospect and bright future.

Russia and China have been partners in the Shanghai Cooperation Organization, also known as the Shanghai Pact, since June 2001. But Moscow and Beijing both emphasized that the great success of Putin's visit and the far-reaching agreements concluded during it would propel their global strategic partnership to higher levels than ever before.

Due to their cooperation on nuclear energy, the two countries agreed on the construction of the Tianwan nuclear plant in Lianyungang in East China's Jiangsu Province, which aimed to be the largest project in the two countries' bilateral economic cooperation. The project laid the foundation for future cooperation on the peaceful use of nuclear energy (Xinhua, 2006).

On April 2006, the construction of the pipeline from Russia to China was finally launched. The route of the pipeline started from Russian Tayshet to Skovorodino and a branch to Chinese Daqing was planned to be finished by the end of 2008.

One month earlier, on March 2006, Sinopec and Rosneft signed a Memorandum of Cooperation and agreed upon the joint acquisition of Russian Udmurtneft assets planned to be sold by TNK-BP. Sinopec had completed the acquisition of a 96.86 percent stake in Udmurtneft, an oil-producing unit of TNK-BP, for a total of USD 3.5 billion. Rosneft and Sinopec entered an Option Agreement whereby Rosneft would acquire the shares of Udmurtneft from the Chinese company, should the latter (Sinopec) have won a tender on the Udmurtneft acquisition from TNK-BP. Rosneft and Sinopec under the said agreement were to establish a joint venture to manage Udmurtneft production activities with the Russian company holding a 51 percent stake and the Chinese - 49 percent. In June 2006, Sinopec was pronounced the winner by TNK-BP upon the open auction for 
the shares of Udmurtneft, and in August the company completed the acceptance of properties from the previous owner. On November 11, 2006, Rosneft and Sinopec signed a shareholder agreement establishing the joint management principles for the jointly acquired Russian company of OJSC Udmurtneft, and on November 13, the companies signed a share transfer agreement regarding Udmurtneft shares allocation to the joint management venture through which Rosneft and Sinopec would control Udmurtneft (Rosneft, 2006). This deal was the first Chinese purchase in Russian energy market and symbolized the active penetration of China into it.

China was also actively penetrating other possible ways of closed energy cooperation and supply with Russia. On August 2006, China brought its drilling platform "Cantan -3" as participant of the project "Sakhalin-3" on extraction of hydrocarbonic fuel at the Sakhalin shelf. Supply of oil, under this project, was estimated at 800 million tons, of natural gas - over 900 billion cubic meters (Vladivostok Times, 2006).

On October 2006, Russian state-owned oil company Rosneft and China's CNPC signed a protocol to set up a joint venture, Vostok Energy, to develop and produce mineral resources in Eastern Siberia. China financed the development stage in exchange for access to Russian deposits and stable deliveries of oil and petrochemicals. The venture's authorized capital was evaluated as $\$ 10$ million. Rosneft would control 51 percent of the company, and CNPC would hold the remaining 49 percent. CNPC became Rosneft's official partner in March 2006, when the two companies signed a memorandum to establish the venture (Kommersant, 2010).

Among other things, it was agreed that the new company would conduct geological and exploration work in Russia, develop mineral deposits and obtain licenses for the use of mineral resources.

Both partners had clear goals. China would gain access to production licenses, which would enhance its potential as a buyer of hydrocarbons. In turn, Rosneft expected the Chinese company to fund the exploration of East Siberian deposits and was seeking a stake in Chinese refining facilities in exchange for deliveries of oil and petrochemicals to China.

The Vostok Energy project became another major step towards closer energy cooperation between the two countries.

In 2007, China decided to actively cooperate with Russia on the supply of natural gas, as the importance of this natural source of energy came to the stage.

On November 2007, CNPC and Gazprom agreed on the gas pricing deal which launched a major pipeline plan. The two sides had agreed on the pricing mechanism for fuel piped from Russia to China after months of negotiations.

Beijing held state-fixed gas prices below international market levels, while Gazprom asked that the gas export price for China should be at comparable level with supplies to Europe, after taking transportation costs into account. Russian media reported that China was refusing to pay more than $\$ 100$ per 1,000 cubic meters, similar to current Russian domestic prices and far below the European price of around $\$ 250$ per 1,000 cubic meters (Fedosova, 2006). Gazprom, which had a monopoly on export of the fuel, was waiting for a deal to be reached to start construction.

But eventually, it was agreed that two pipelines either side of Mongolia would deliver up to 80 billion cubic meters of gas a year-almost double the amount the company was selling to Germany, its top customer in Europe. The first pipeline would be fed with output from western Siberian fields. Gas for a second pipeline could come from Sakhalin and maybe the Kovykta field in East Siberia (Graham-Harrison, 2007).

In 2007, Russia and China greatly improved theirs relations in many areas. In March 2007, the Chinese president came to Moscow on a visit in order to participate in the activities devoted to the Year of China in Russian Federation. He was accompanied by the General Directors of the three biggest Chinese energy companies: Sinopec, CNPC and China National Offshore Oil Corporation. Both leaders signed a joint declaration about further cooperation in numerous energy related projects and signed a further series of agreements and contracts worth more than US\$4.3 billion (China Daily, March 21, 2007).

In October 2007, the Chinese Premier Minister Wen Jiabao went to Moscow to participate in the closing ceremony of the Year of China and Russia and that time more then 10 agreements on energy cooperation were signed.

In 2008, the new Russian president Medvedev came to power. Though it was not a power shift, as his presidency was more then predictable and Putin took the position of the Prime Minister, China still needed to be reassured that he would continue the policy of his predecessor (China Daily, May 21, 2008). 
China appreciated the fact that the new Russian president chose China for his first foreign visit outside the CIS. The significance of the visit of Medvedev to China, which took place on 23-24 May 2008, was highlighted by the signing of a Joint Declaration outlining their agreement on major international issues (Note 2).

This document reaffirmed the commitment of both countries to civilization and cultural diversity within the world community and to the formation of a multipolar world. Medvedev and Hu Jintao continued the tradition of regular meetings (several times a year) to exchange views on pressing international and bilateral issues, which were established during the presidency of Vladimir Putin.

Moreover, in 2008- 2009 contact between the leaders of both countries became more intense: apart from the official visits (Hu Jintao visited Russia in June 2009) and meetings on the sidelines of the G8 summit, APEC and the SCO, there were bilateral meetings at the summit of BRIC (Yekaterinburg, Russia, June 2009) and the G20 (three times).

These multi-level mechanisms made practical interaction more effective. An 'Action Plan for 2009-2012,' aimed at the implementation of the 'Treaty of Good-neighborliness, Friendship and Cooperation' was adopted by the two countries. A Russian-Chinese energy dialogue took place at the level of vice-premiers, which helped to conclude new agreements on cooperation in the oil and gas sector, including agreements on building the Skovorodino-Daqing oil pipeline, and on the provision of a Chinese bank loan of $\$ 25$ billion to Russian oil companies "Transneft" and "Rosneft". This loan should be reimbursed by Russia's future pipeline oil deliveries to China (300 million tons within 20 years, starting from 2011). During the 14th regular meeting in October 2009 in Beijing, the two countries' prime ministers reached an agreement on the supply of Russian natural gas to China starting from 2014-2015 (up to 70 billion cubic meters) (Woods, 2008).

In the investment sphere, bilateral cooperation received an additional stimulus: In June 2009, the heads of state approved a plan for Russian-Chinese cooperation in the investment sphere, and in September 2009, approved a program of cooperation between the regions of the Russian Far East and Eastern Siberia, and the Chinese North-East for 2009-2018, including in the fields of resources excavation, manufacturing, and transport facilities construction.

In 2009, China and Russia also signed a formal agreement that provided Chinese capital today in exchange for Russian oil tomorrow. Long-term loans provided by China to Russia totalling $\$ 25$ billion breakdown into $\$ 15$ billion going to the Russian oil company (and effectively the Russian state oil holding company) "Rosneft" and $\$ 10$ billion to the Russian state oil transportation company "Transneft". In return, Russia agreed to repay the loans by providing China with 300 million tons of oil, at an average annual volume of 15 million tons or approximately 110 million barrels of oil per year, from 2011 to 2030 (Rosner, 2010). Volumes will increase over time once both segments of the Eastern Siberian-Pacific pipeline are completed . The loans-for-oil agreement supports China's energy security through land-based energy transport, avoiding the key oil maritime choke-points of the Straits of Hormuz and the Straits of Malacca for tankered oil. It is yet another guaranteed source of oil supply for nearly the next two decades and, depending on the ultimate financial arrangements of the loans-for-oil agreement, a relatively cheap source of foreign imported oil.

Other notable achievements in the Russo-Chinese energy field in 2009 have been the purchase by the Russo-Chinese Energy Investment Company of a 51 percent stake in the Russian oil and gas company "Suntarneftegaz" (Portyakov, 2010)

China also obtained the development and production rights to two gas fields in East Siberia, which were more important for their political significance than for the amount of prospective gas the fields contain. The share of natural gas in China's energy mix is paltry given its heavy dependence on coal (64 percent of Chinese imported coal comes from Russia) and hydropower, but the increase in gas fired electricity generation is expected to significantly increase over the next two decades.

To this end, in 2009 the Russo-Chinese relationship had manifested itself in a number of practical and tangible ways. In December 2009, Russian Prime Minister Vladimir Putin opened a new oil export terminal that served as a key gateway for Russian energy exports to Asian markets. According to Russian information sources, the opening of the new oil terminal at Kozmino, near Nakhodka, pushed Russia closer to its strategic goal of diversifying its energy exports away from Europe and towards the Pacific Rim. This should allow, according to Russia's own updated energy strategy, for it to increase crude oil and oil product exports to the Asia-Pacific region to 22-25 percent (from 8 percent now), and to launch the export of natural gas to 19-20 percent (from a zero, flat-line basis now) (Rosner, 2010). This latter estimate, if it excludes Sakhalin LNG, would appear widely optimistic. However, if China proves serious about developing its natural gas transport infrastructure and 
gas-fired power generation, then these numbers could come to represent a more realistic assessment of Russia's Chinese dimension.

More recent developments in energy have been mostly catalyzed by the fall in global oil prices since 2008 and a dramatic weakening of natural gas prices across Europe, providing the single largest stimulus for intensified Russo-Chinese cooperation in the energy field. At the same time it is altogether unclear that China's inward foreign investment (loans) to Russia will necessarily end up directly benefiting China beyond the loans-for-oil agreement. These dollars may very well end up being re-circulated to shore up Transneft's dilapidated yet larger and more strategically important east-west infrastructure investment to the European gas market, where for much of the next decade its real fortunes lay (Rosner, 2010).

This observation is made in calculations that European gas market demand may not return to 2008 levels until after 2015 (Honore, 2011). Russia's re-accession to 'great power' status derives directly from its ability to control and manipulate its downstream gas markets, particularly in Central and Eastern Europe. Preventing a loss of market in Europe is considered a high priority in Russian business and political leadership-circles as is its continued leverage over the Ukraine (which continues to serve as the largest transit country for Russian gas to downstream Europe).

In September 2010, Russian President Dmitry Medvedev visited China to boost bilateral energy cooperation and inaugurate a new oil pipeline. "The smooth completion of the pipeline project is a model for two countries mutually beneficial win-win cooperation and a milestone for China-Russia energy cooperation," said Hu Jintao. The ceremony came after the two held talks, during which Hu said the two sides should strive to ensure the safe operation of the project. Medvedev said the pipeline will help create closer ties between the two countries (Forbes, 2010).

Representatives of CNPC and Transneft reported the completion of the project via live video-audio broadcast. The pipeline starts in Skovorodino and enters China at Mohe country before going to Daqing. Under this deal, China made a 25 billion USD long term loan to Russia while Russia agreed to supply China with 300 million tons of oil through this pipeline form 2011 to 2030 (China Daily, September 27, 2010).

\section{Problems of Sino-Russian Energy Cooperation}

As a result of recent developments Russia became China's fourth largest energy provider, providing approximately 9 percent of Chinese imports. A doubling of this percentage may occur over the next decade, especially if Russian gas comes online in China. But, firstly, the countries will have to find ways to solve existent problems which constrain current energy cooperation. These problems are conditioned by the following factors.

\section{1) Changes in the structure of international energy market and position of both countries}

There was a reluctance among the Chinese leadership, notably then-Premier Zhu Rongji, who was in charge of China's economy, to invest in transnational pipelines - the project economics of which are less attractive the lower the price of oil - and the acquisition of oil exploration and production assets abroad when oil could be purchased so cheaply on the international market. The Chinese also stalled the oil and gas pipeline negotiations in the hope of gaining price concessions from the Russians.

The rise in world oil prices over the past decade shifted the power in the China-Russia energy relationship from China to Russia. The increase in the average annual price of oil from $\$ 14$ per barrel in 1998 to $\$ 72$ per barrel in 2007 and China's own oil consumption and import growth over this period-a source of upward pressure on world oil prices — created anxiety in Beijing about the security of China's oil supply (Downs. 2010). This energy insecurity made Beijing increasingly eager to finalize the oil and gas pipeline negotiations.

Unfortunately for China, the feeling in Russia was not mutual. The rise in oil prices fuelled the growth of resource nationalism in Russia, motivating Moscow to expand its control over oil and natural gas resources. For Moscow, greater state control of energy assets is not only a way to revitalize its economy but also a means to achieve international political and economic gains.

The emergence of higher oil prices and Russian resource nationalism were an unwelcome surprise to China. The Chinese government had to face the reality that the world's oil and natural gas markets changed from a buyer's to a seller's market.

The sharp rise in natural gas prices also contributed to the lack of progress on the Kovykta pipeline by rendering the low prices insisted on by the Chinese even more unattractive to the Russians. Sino-Russian negotiations over 
the export of Russian natural gas to China have collapsed repeatedly over China's refusal to pay internationally competitive prices for natural gas.

2) The influence of domestic "interest groups" in Russia

The power struggle in Russia's interest "groups" is close to the energy business and the struggle for redistribution of spheres of influence resulted in the pro-government and pro-European company Gazprom taking the leading place in the exploration and export of Russian energy recourses, and China's oriented company Yukos and its affiliates losing their control (Klussmann, et,al., 2007). Indeed, both the oil and gas pipeline projects have been hindered by the involvement of private companies, whose control of export pipelines would undermine Moscow's ability to use energy exports for foreign policy leverage.

In the case of the oil pipeline, an important factor behind the abandonment of the Angarsk-Daqing route - and its replacement with the ESPO pipeline and spur to China - was the fact that the principal Russian supporter of the Angarsk-Daqing oil pipeline was Yukos, a private oil company increasingly resented by the Kremlin and Russian state oil companies. Additionally, with the reassertion of state control over the energy sector, the Kremlin and the Russian state energy firms became increasingly irritated with CNPC for continuing to negotiate with Yukos rather than the Russian state.

Indeed, one of the lessons China learned from the "Yukos Affair" was to only negotiate with Russian state energy companies. In the case of the natural gas pipeline the position from Gazprom has substantially delayed the plans of the private and half-foreign firm TNK-BP to export gas from the Kovykta field.

3) Orientation of the Russian Foreign policy

In terms of the hierarchy of foreign policy priorities in Beijing, the relative weakening of Russia objectively increases the importance of relations with the West and especially with the United States. Indeed, this factor will most likely have a greater impact on Sino-Russian cooperation in the future than it has before. Another important variable likely to impact on Russian-Chinese relations in the upcoming years will be the "2012 factor" - this year will see the election of a new president in Russia, as well as the renovation of the top party and state leadership in China. This consideration should be taken into account with regard to the future prospects of bilateral relations.

4) Absence of concrete strategy and policy towards cooperation with Russia

China has no concrete strategy towards energy cooperation with Russia. Several documents were signed, but all of them lack the concrete and long term measures and stages of cooperation. Most of the negotiations on projects were undergone on energy companies' levels and did not receive the support of the Chinese government.

5) Lack of competitiveness of local companies at the international struggle for energy resources

Chinese companies lack competitiveness on the world's arena. European companies secure most of all the attractive projects, because such companies have strong governmental support, wish to take risks and have more knowledge and resources in energy cooperation. Now the main partners of Russia are Shell, British Petroleum and the Exxon. Even despite the growing tension between Russia and Western Europe in the world arena, energy interests are still behind these political decisions.

6) The Lack of critical infrastructure

China and Russia need to construct additional infrastructure to expand energy trade and to make it more cost-effective in the long term. Currently, the majority of Russia's oil exports to China are delivered by rail, which is about two and a half to three times as expensive for Russian oil producers as shipments by pipeline and may not be economical in the absence of high oil prices. A pipeline or LNG facilities are also required for the delivery of natural gas from Russia to China.

7) The appearance of the conception of "Chinese threat"

The appearance of a perceived "Chinese threat" because of the rapid immigration of Chinese to the Russian Far East made a negative contribution to energy cooperation between the two countries. Local governments were lobbying the anti-Chinese projects in order to satisfy the population demand to stop 'selling to China.'

There is a sense of weakening in the mutual 'camaraderie and partnership' between the two nations that reached its high-point during the Cold War but has since declined. There is also a growing recognition that rising Chinese power may result in growing dissatisfaction from Russia who may feel Chinese ascendancy is in part being fuelled by Russian resources (Rosner, 2010). This throws a perceptual wrench into the works of the Russo-Chinese 'strategic partnership', particularly where energy is concerned. 
8) Impact of the global financial crisis 2008

The level of bilateral trade between the two countries suffered as a result of the financial crisis. Turnover in trade between Russia and China had increased from $\$ 8$ billion in 2000 to $\$ 56.8$ billion in 2008 - just slightly below the level of $\$ 60$ billion, which was declared as a target for 2010 (Portyakov, 2010). However, from September 2008, the volume of trade began to decline. The decrease in Russian-Chinese trade turnover was caused by the deteriorating economic environment and declining investment and consumer demand in Russia, by the depreciation of the rouble, which resulted in the higher cost of imported goods from China and, finally, by lower world prices for oil and petroleum products, which provided over half of Russian exports to China by cost. As a result, in 2009, the volume of Russo-Chinese trade declined, according to Chinese customs statistics, by 31.8 percent - to $\$ 38.8$ billion. Chinese exports to Russia fell by 47.1 percent - to $\$ 17.5$ billion, and Chinese imports from Russia declined by 10.7 percent - to $\$ 21.3$ billion (Portyakov, 2010).

The energy politics of other countries also affected Sino-Russian significantly. The following are the most important:

9) Japanese factor

Japan pays high interests in importing Russian gas and oil, as the country is 100 percent dependent on energy resources import. Japan played a crucial role in the failure of the project oil pipeline from Angarsk to the Chinese pipeline network at Daqing, proposing and financing the route from both West and East Siberia to the Pacific coast port of Nakhodka. Japan wanted the Nakhodka export terminal to be the pipeline's only outlet, because it was worried that if the Chinese link was built Beijing would end up with the lion's share of Russian oil exports. This proves that Russo-Chinese cooperation is very fragile and based on economic, but not strategic interests.

\section{0) American factor}

The USA also wished to diversify its own energy supply and to obtain oil and gas from Russia's Far East, especially after the events of $9 / 11$. Along with intensification of antiterrorist cooperation with Russia, the Bush administration also underwent more active policy towards energy cooperation with Russia. In May 2002, the Declaration on energy dialogue between the two countries was signed and the construction of pipeline from Russian Siberia through Barents Sea to USA was constructed. Up until 2015, this pipeline will supply 50million tons of crude oil per year to the USA. From 2020, the volume will be increased up to 80million tons (Chow, 2003). This played an important role in ensuring Russia that the country is very welcomed in the international energy market and can choose partners on the basis of the more the better.

11) Korean factor

South Korea is one of the four biggest energy importers in the world. Similarly to China, the main source of energy supply for Korea is the oil from the Middle East. Korea wished to participate in projects of oil and gas supply from Russia and thus the country supported the project of pipeline construction to Nakhodka using the Korean national groups that are quite influential in Russian Far East.

\section{Conclusion}

Despite these problems, Sino-Russian energy dialog has significant reserves and both countries objectively need to improve and deepen their strategic partnership. Energy cooperation plays an important role in strengthening the strategic partnership between the two countries, and they wish to make join efforts to boost this area.

Good perspectives of Sino-Russian energy cooperation depend on three factors. First, cooperation shall be in their bilateral interests, and then both countries will be obviously interested in sustaining and developing these relations. Second, energy cooperation between the two countries should rely on strong strategic partnership, which will provide greater support for the energy dialogue. Lastly, the leaders of both states should pay great attention to the energy relationship and provide strong support. It should be an important issue on the agenda of high-level relations. As such, the energy sector of China and Russia as well as energy companies will be more assured and eager to promote cooperation.

If this occurs, it seems obvious Sino-Russian energy cooperation will develop positively and dynamically in the foreseeable future.

\section{References}

Andrews-Speed, Phillip. (2009). China and Russia: Is CNPC About to Ride Again to the Rescue of Rosneft? Retrieved November 15, 2011, from http://www.dundee.ac.uk/cepmlp/gateway/index.php?news=29542

Blagov, Sergei. (2005). Russia Walks the Line between Japan and China. Retrieved December 7, 2011, from http://www.atimes.com/atimes/Central_Asia/GA05Ag01.html

China Daily. (2006, March 7). Putin to visit China this month. Retrieved November 14, 2011, from http://www.chinadaily.com.cn/english/doc/2006-03/07/content_527832.htm 
China Daily. (2006, March 17). China, Russia to build gas pipeline. Retrieved November 11, 2011, from http://english.peopledaily.com.cn/200603/17/eng20060317_251499.html

China Daily. (2007, March 21). China, Russia to Sign 4.3 b\$ Deals during Hu's Visit. Retrieved December 22, 2011, from http://www.chinadaily.com.cn/china/2007-03/21/content_833393.htm

China Daily. (2008, May 21). Medvedev's visit to consolidate ties. Retrieved November 12, 2011, from http://www.chinadaily.com.cn/china/2008-05/21/content_6700460.htm

China Daily. (2010, September 27). China, Russia Mark Completion of Crude Oil Pipeline. Retrieved December 3, 2011, from http://www.chinadaily.com.cn/business/2010-09/27/content_11354901.htm

Chow, Edward. (2003). U.S.-Russia Energy Dialogue: Policy, Projects, or Photo Op? Foreign Service Journal, $80(12)$.

Datamonitor Research Store. (2002). Slavneft: Auctioned for a Pittance Retrieved. Retrieved November 2, 2011, from http://www.datamonitor.com/store/News/slavneft_auctioned_for_a_pittance?productid=0B34C54F-F36B-4 C0F-AE22-CE490BC7D1CA

Downs Erica S. (2010). Sino-Russian Energy Relations: An Uncertain Courtship. In James Belacqua (Ed.), The Future of China-Russia Relations (pp. 146-178). The University Press of Kentucky.

Fedosova, Y., V. (2006). Gas Appetite of the Celestial Empire: Atomic Mix? Retrieved. Retrieved December 17, 2011, from http://www.proatom.ru/modules.php?name=News\&file=article\&sid=481

Forbes. (2010). Russia - China Energy Deal in the Works. Forbes. Retrieved November 19, 2011, from http://www.forbes.com/2010/09/29/russia-china-energy-partnership-business-energy-oxford-analytica.html

Graham-Harrison, Emma. (2007). China, Russia Reach Gas Price Agreement. Reuters, 1325.

Honore Anouk. (2010). The EU Gas Market Development. Retrieved November 14, 2011, from http://www.bergen-energi.com/arch/_img/9223145.pdf

Klussmann Uwe, Neef Christian, \& Schepp Mattias. (2007). Putin's Risky Bid to Hold on Power. Retrieved November 20, 2011, from http://www.spiegel.de/international/world/0,1518,510426-2,00.html

Kommerstant. (2010). CNPC and Rosneft Expand Cooperation. Retrieved November 18, 2011, from http://www.kommersant.ru/Daily/55779 (In Russian).

Peoples Daily. (2003). Angarsk - Daqing Line Adopted for Priority Construction. Retrieved December 2, 2001, from http://english.peopledaily.com.cn/200305/23/eng20030523_117109.shtml

Portyakov, Vladimir. (2010). Russian-Chinese Relations: Current Trends and Future Prospects. Russian Analytical Digest, 73.

Rosneft. (2006). Udmurtneft Holds General Extraordinary Meeting of Shareholders in Moscow. Retrieved November 27, 2011, from http://www.rosneft.com/news/pressrelease/10642.html

Rosner, Kevin. (2010). Sino-Russian Energy Relations in Perspective. Retrieved November 23, 2011, from $\mathrm{http} / / /$ www.ensec.org/index.php?option=com_content\&view=article\&id=260:sino-russian-energy-relationsin-perspective \&catid $=110$ :energysecuritycontent\&Itemid $=366$

Sieff Martin. (2009). Shifting Superpowers: The New and Emerging Relations Between the Unites States, China, and India. CATO Institute.

Vladivostok Times. (2006). China is Preparing for the Sakhalin -3 Project Exploring. Retrieved November 18, 2011, from http://vladivostoktimes.ru/show/?id=212\&f_day=18\&p=249

Woods Shelton. (2008). Oil for China: The Sino-Russian Waltz. Journal of Energy and Development, 33(2), Spring, 249-266.

Xinhua. (2006, March 16). Putin to discuss energy cooperation with China during visit. Retrieved October 24, 2011, from http://news.xinhuanet.com/english/2006-03/16/content_4310195.htm

\section{Notes}

Note 1. The full text of the "Treaty of Good-Neighbourliness and Friendly Cooperation between the People's

Republic of China and the Russian Federation" dated July 24, 2001 is available: http://www.fmprc.gov.cn/eng/wjdt/2649/t15771.htm (November 4, 2011).

Note 2. Full text of the "Joint Statement of The People's Republic of China and the Russian Federation On Major International Issues" dated May 23, 2008 is available: http://www.fmprc.gov.cn/eng/wjdt/2649/t465821.htm (November 8, 2011). 